\title{
Hydrodynamic Salts Dispersivity Model in the Delta of Wadi El Arish, North Sinai, Egypt
}

\author{
Ezz El-Din El-Tablawi M. Saad and Jihan El Husseiny T. Abd El Aal \\ Hydrology Department, Desert Research Center, Cairo, Egypt,
}

\section{A R T I C L E I N F O}

Article history:

Received 04 December 2014

Accepted 20 January 2015

\section{Keywords:}

Quaternary aquifer;

Wadi El Arish;

North Sinai, Egypt;

Hydrodynamic salts;

Dispersivity model.

\begin{abstract}
A B S T R A C T
Delta of Wadi El Arish is suffering from encroachment of seawater due to the over exploitation of groundwater from the Quaternary aquifer. Continuous deterioration of the limited sole resources of water (groundwater) is expected for both quantitatively and qualitatively measures. Our objective in the current study is to develop complete mathematical model in order to describe the transport in subsurface of salts dissolved in the water that occupies the void space. These dissolved salts determine the groundwater quality. Hydrodynamic salts dispersivity model is constructed to carry out the mass balance of water and salts and the interrelationship of physical processes affecting on the salts mass transport in the Quaternary aquifer in the Delta of Wadi ElArish. The rate of chemical reactions in the groundwater and delineating of seawater-fresh groundwater interface are defined. The obtained results indicate that the effective porosity varies from 0.02 to 0.3 . An increase of dissolved salts from about 0.1 $\mathrm{kg} / \mathrm{m}^{3}$ to $2.5 \mathrm{~kg} / \mathrm{m}^{3}$ in some localities while other decrease from $0.1 \mathrm{~kg} / \mathrm{m}^{3}$ to 1 $\mathrm{kg} / \mathrm{m}^{3}$ is recorded in other localities. The retarded velocity varies from $0.003 \mathrm{~m} /$ day to $2 \mathrm{~m} /$ day. The mechanical dispersion coefficients vary from $<5$ $\mathrm{m}^{2} /$ day to $120 \mathrm{~m}^{2} /$ day. Furthermore, different variations of hydrodynamic salts dispersivities are indicated, where the value of Peclet number ranges from 0.4 to $>$ 40. Slow and fast reactions are detected. The proposed model expressed seawater-fresh groundwater interface and travel time variations of miscible and groundwater salt particles for the Quaternary aquifer in the Delta of Wadi El Arish area.
\end{abstract}

\section{Introduction}

The present work is very useful for complete both qualitative and quantitative management of groundwater in the Delta of Wadi El Arish area. Hydrodynamic salts dispersivity model is developed. It is interacted completely with the hydraulic flow model that has been constructed by Abd Aal ${ }^{[1]}$ for studying the groundwater movement in the Delta of Wadi El Arish. Hydrodynamic salts dispersivity model is basic issue for carrying out applicable groundwater exploitation plan and protect it from deterioration resulting from seawater encroachment. Increasing of salts mass fraction represents one of the contaminants affecting on the groundwater quality of the Quaternary aquifer in the studied area. The proposed model is applied in order to carry out the interrelationships of different physical processes that influencing the salts transport in the groundwater system. It detects also the rate of chemical

\footnotetext{
* Corresponding author.

E-mail address: Ezz1960@hotmail.com
}

reaction in the groundwater and seawater-fresh groundwater interface in the Delta of Wadi El Arish area, as well as, it estimates the water and salt balances of the Quaternary aquifer in the studied area. The studied area received the attention of number of workers in the field of geology, hydrogeology, geochemistry and modeling ${ }^{[1-}$ 4]. The studied area is located in the northeastern coast of Sinai peninsula (Fig. 1). It occupies an area of about $192.2 \mathrm{~km}^{2}$. It is dominated by an arid climate with an annual rainfall intensity of $150 \mathrm{~mm} / \mathrm{year}$. It is characterized by over pumping of groundwater for domestic and agricultural use. Over exploitation of groundwater in the studied area lead to continuous quantitative and qualitative deterioration.

\section{Hydrogeological conditions}

The water bearing formation in the Delta of Wadi El Arish area represents a complex system consists of three water bearing rock units (Fig. 2). They are hydraulically connected and forming one hydrogeological aquifer system. They are defined from top to base as follows: 
1- Sand dunes (Holocene deposits.)

2-Alluvial deposits, which are mainly composed of quartz sand, gravel, fine calcareous silt and clay (Pleistocene deposits).

3-Complex calcareous sandstone (Kurkar), which dominates the whole coastal zone and inland southward to about $13 \mathrm{~km}$ from the coast line (Pleistocene rock unit).

The groundwater flows generally from South at Lahfan fault to North towards the Mediterranean sea and from East at Wadi El Maazer to West. The hydrogeological boundary conditions are considered as follows:

1- A constant head boundary at northern direction (Mediterranean Sea).

2- A permeable fault (Lahfan fault) at South and southeastern direction.

3- Changing in head pressure boundary in the West and northwestern directions.

4- Changing in head pressure boundary in the East and northeastern directions.

5- The Quaternary aquifer is underlined by impermeable Pliocene bed.

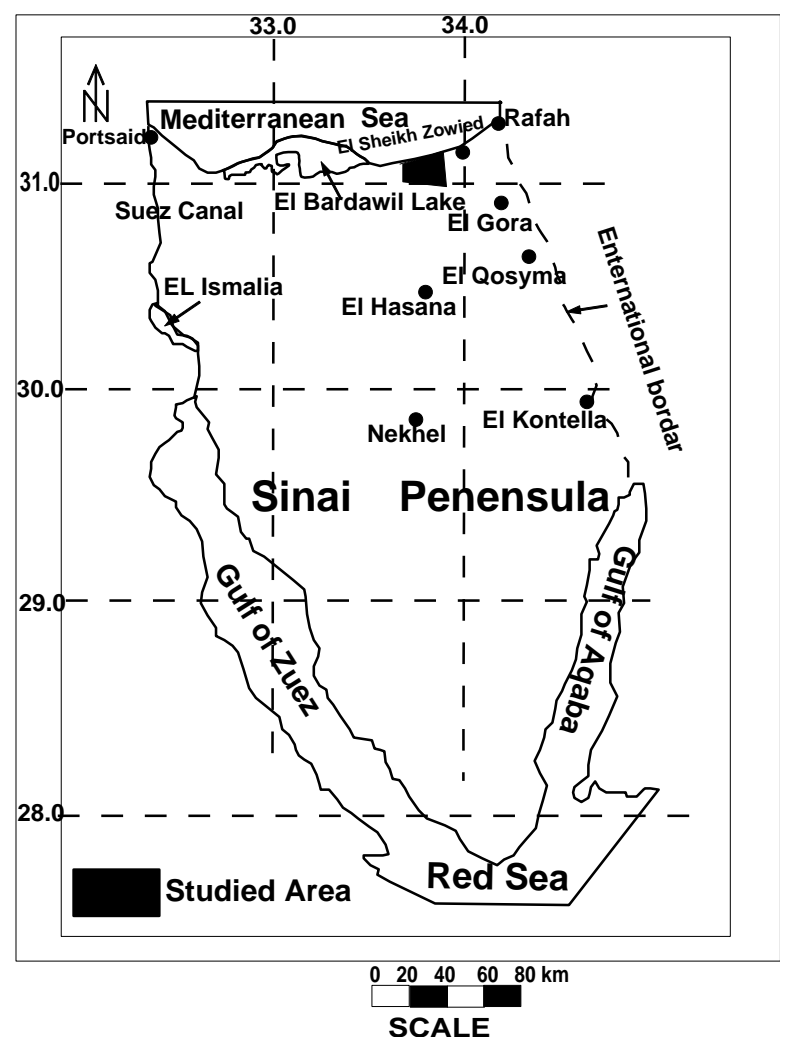

Fig. 1: Location map of the studied area

\section{Hydraulic flow model background}

The hydraulic flow model in the Delta of Wadi El Arish area was constructed by Abd El Aal ${ }^{[1]}$ applying the available data at that time. It uses MODFLOW program (version 5) for windows ${ }^{[5]}$. The model was designed for an area of about $192.2 \mathrm{~km}^{2}$ and network was defined as regular square cells with cell dimension $250 \mathrm{~m}$ x $250 \mathrm{~m}$. It was constructed by considering the above mentioned boundary conditions and representing one complex formation of groundwater system. The Pliocene formation is considered as underlying impervious layer. The aquifer is recharged by the following different sources as reported by Abd El Aal ${ }^{[1]}$ :

1- Direct precipitation (rainfall) on the coast with a rate of $10000 \mathrm{~m}^{3} /$ day.

2-Vertical leakage of groundwater from deep Cretaceous Formation along Lahfan fault system in southern area with a rate of $20000 \mathrm{~m}^{3} /$ day as well as a subsurface flow through Wadi El Maazar in the eastern area.

The groundwater is pumped out from 235 wells tapping the Quaternary aquifer with a rate of $45000 \mathrm{~m}^{3} /$ day in the winter season, changes to about $90000 \mathrm{~m}^{3} /$ day in the summer season. The model is calibrated for transient state according to a field survey data was carried out in the year 2005. The model was calibrated, where the values of the horizontal hydraulic conductivity of the complex system were defined for each cell. These values from $10 \mathrm{~m} /$ day in the western area to $80 \mathrm{~m} /$ day in the eastern area. While, the diffusivity coefficient varies from $700 \mathrm{~m}^{2} /$ day in the western area to $30000 \mathrm{~m}^{2} /$ day in the eastern area.

The results of the hydraulic flow model indicate that the studied area is subjected to an increasing of pumping along the coastal line and inland area. The above results reflect a drop in the groundwater level ranges from $1 \mathrm{~m}$ to $5 \mathrm{~m}$ after ten years prediction. The lowering in the groundwater level is leads to seawater encroachment in the studied area and deterioration of the fresh groundwater resources.

\section{Conceptual model}

The present work initiated a design of a conceptual model for the area of Wadi El Arish. The water bearing formation in the Delta of Wadi El Arish is considered as complex system of groundwater under unconfined to semi confined conditions. It comprises three water bearing rock units namely; sand dunes, alluvium and kurkar sandstones. They are hydraulically connected (Fig. 3). Salts mass fraction due to dispersion and diffusion is coming from the Mediterranean Sea in the North and normal to the direction of flow. This transverse dispersion is caused by diverging flow paths in the Quaternary aquifer that transport salts masses from the seawater to spread laterally from the main direction of flow. In the current study, three dimensions of salts plumes are utilized. The transverse dispersions are much less than longitudinal dispersions. The shape of the salts plume tends to be elongated in the direction of flow. While, advection process in the studied area is represented by movement of salts with flowing groundwater of higher water table from Lahfan fault and medium water table from the eastern direction at Wadi El Maazar according to seepage velocity in the pore space. Furthermore an advection of miscible water flow with higher density and elongate shape is recorded in the reverse direction of groundwater flow from Lahfan fault. 


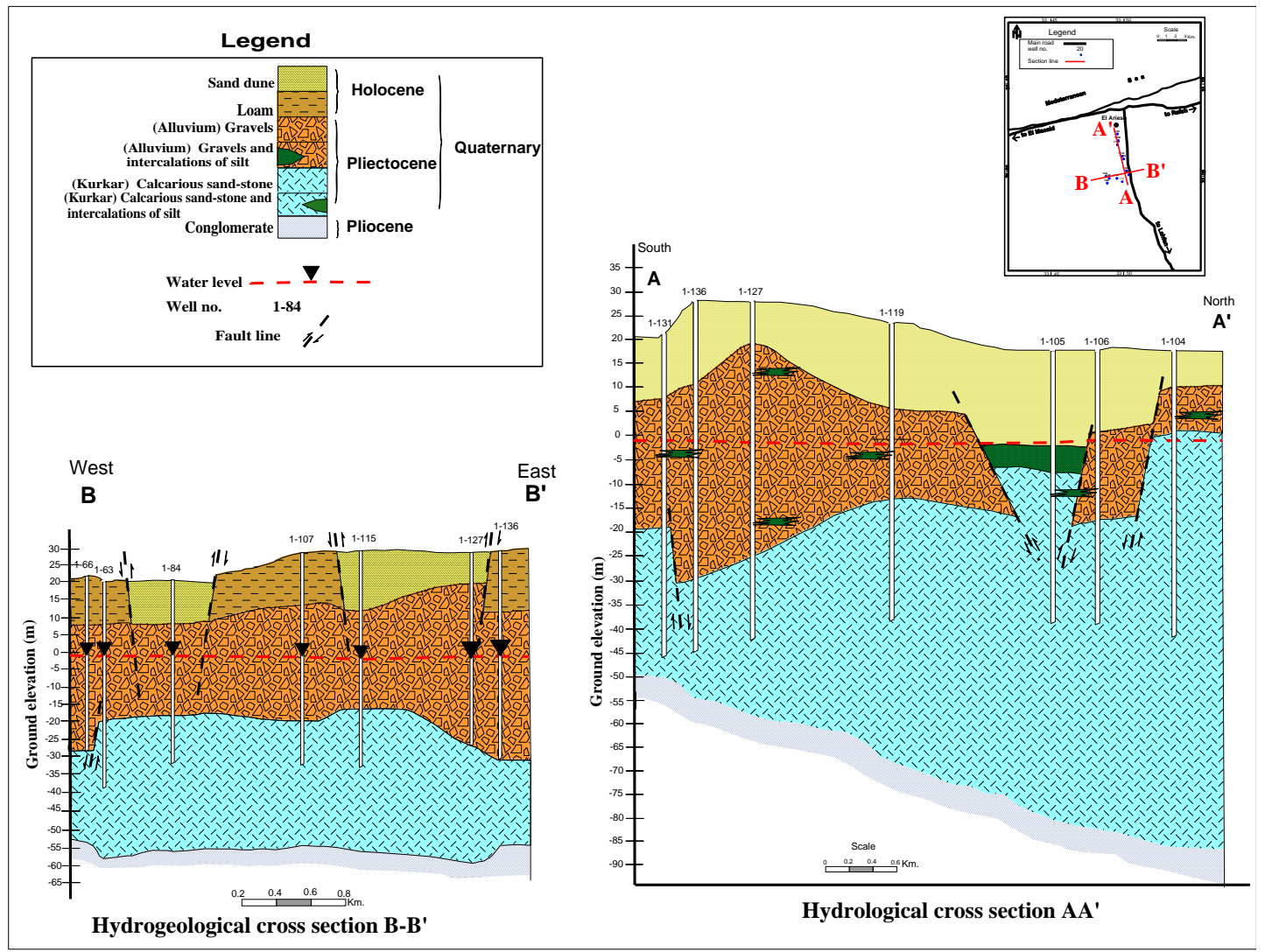

Fig. 2: Hydrogeological cross sections for the quaternary aquifer in the Delta of Wadi El Arish, North East Sinai, Egypt (After ${ }^{[1]}$ )

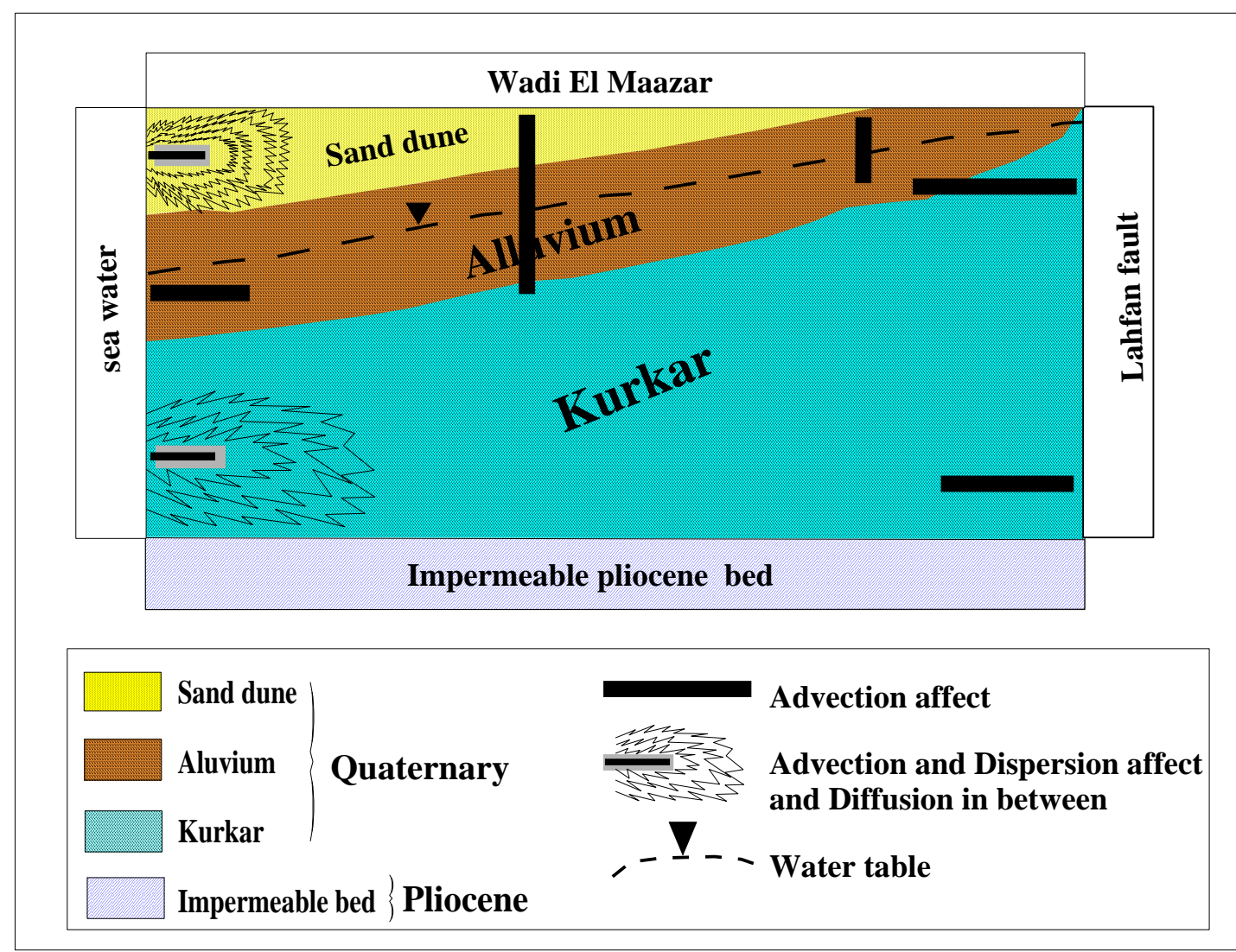

Fig. 3: Conceptual model of the quaternary aquifer in the Delta of Wadi El Arish, North East Sinai, Egypt (applying the procedure of El Tablawi ${ }^{[15]}$ ) 


\section{Design and preparation of the hydrodynamic salts dispresivity model}

Design and preparation of hydrodynamic salts dispersivity model depends on the using MT3D program that linked with MODFLOW program [5]. MT3D computer program is governed by parabolic partial differential equation for transient state as follows ${ }^{[b]}$ :

$$
\begin{aligned}
& \frac{\partial}{\partial X i}\left(\operatorname{Dij} \frac{\partial c}{\partial X i}\right)-\frac{\partial}{\partial X i}\left(\mathrm{CV}_{\mathrm{i}}\right)=\mathrm{Rd} \frac{\partial c}{\partial t}+\lambda \mathrm{C} \mathrm{Rd}-\frac{C^{\prime} W^{*}}{n e} \\
& R d=V / V c=1+K d(P b / n e) \\
& \lambda=0.693 / \mathrm{t}_{1 / 2} \\
& \text { Where; }
\end{aligned}
$$

$X i$ : Cartesian coordinate $(\mathrm{m})$.

Dij: Dispersion coefficient tensor $(\mathrm{m})$.

$V i$ : Seepage or average pore water velocity in the direction of $\mathrm{X}_{\mathrm{i}}(\mathrm{m})$.

C: Solute concentrate $\left(\mathrm{kg} / \mathrm{m}^{3}\right)$.

$R d$ : Retardation factor (dimensionless).

$\lambda$ : Hydrolysis and decay (first order rate constant).

$C^{\prime}$ : Solute concentration in the source or sink $\left(\mathrm{kg} / \mathrm{m}^{3}\right)$.

$\mathrm{W}^{*}$ : Volume rate per unit volume of the source or sink $\left(\mathrm{m}^{3} /\right.$ day $)$.

ne: Effective porosity (dimensionless).

$V:$ Average linear groundwater velocity (m/day).

$V c:$ Velocity of contaminant (m/day).

$K d$ : Distribution coefficient $\left(\mathrm{m}^{3 /} / \mathrm{kg}\right)$.

$\mathrm{Pb}:$ Bulk density of porous media $\left(\mathrm{kg} / \mathrm{m}^{3}\right)$.

$\mathrm{t}_{1 / 2}$ : Half life time (day).

The above equation is affected by numerical errors including a phenomenon known as "Numerical dispersion", which refers to artificial dispersion caused by errors associated with the discretization of the problem domain. To minimize such errors, the grid should be designed so that the Peclet number $(\mathrm{Pe})$ is less than or equal to one ${ }^{[6]}$. Although an acceptable solution may be obtained with $\mathrm{Pe}$ as high as $10^{[7]}$. $\mathrm{Pe}$ is calculated from the following equation:

$\mathrm{Pe}=\frac{\Delta L}{\alpha}$

Where;

Pe: Is the Peclet number (dimensionless)

$\Delta L$ : Is a characteristic nodal spacing (m)

$\alpha$ : Is a characteristic dispersivity (m)

In the proposed model, $\Delta L$ equals $250 \mathrm{~m}$ and $\alpha$ equals $25.6 \mathrm{~m}$. Thus the Peclet number equals 9.8. This means that acceptable solution is taking place.

The hydrodynamic salts dispersivity model is represented by network of regular cells with the same dimension of the hydraulic flow model $(250 \mathrm{~m} \times 250 \mathrm{~m})$. The regular cells cover an area of about $192.2 \mathrm{~km}^{2}$ and discrete to 3075 cells. The current model is designed according to different parameters for advection, dispersion and diffusion in non uniform flow field.

These parameters include the following:

1-Advection parameters: which comprise the following:

a- Courant number.

b- Concentration weighting factor. c- Critical relative concentration gradient.

d- Conditions of salt particles within the cell.

A fourth-order Runge-Kutta method involves calculating the velocity of the particle at four intermediate points for each tracking step ${ }^{[6]}$. While Hybrid MOC/MMO (HMOC) solution scheme is used for automatic adaptation of solution process to the nature of the concentration field.

2-Dispersion parameters; which comprise the following:

a- Longitudinal dispersivity; the value of this parameter is scale dependant and occurs along the direction of groundwater flow. It varies with the width along the mass flux direction. This parameter is estimated as $25.6 \mathrm{~m}$ from the model calibration as discussed later.

b- Transverse dispersivity; it is the dispersivity perpendicular to the mass flux direction ${ }^{[8]}$. It varies from $10 \%$ to $20 \%$ and from $1 \%$ to $2 \%$ of longitudinal dipersivity in the horizontal and vertical direction, respectively ${ }^{[8]}$. It is estimated in the proposed model as $2.56 \mathrm{~m}$ and 0.256 in the horizontal and vertical directions, respectively.

c- Effective molecular diffusion; it is calculated as a result of molecular diffusion and tortuosity ${ }^{[9]}$. It is estimated in the current model as $6.048 \times 10^{-5} \mathrm{~m}^{2} / \mathrm{day}$. Generally the diffusion is the movement of dissolved components in the water in response to a chemical concentration gradient i.e. movement from high concentration to low concentration in random motion of molecules ${ }^{[10]}$. Usually molecular diffusion is only found to have effects at very low velocities or long period of travel ${ }^{[11]}$.

\section{Calibration and running the model}

Hydrodynamic salts dispersivity model is calibrated for transient state to represents the salts transport depending on the hydrogeological and hydrochemical boundary conditions in order to approximate the field data of the salts concentration in the groundwater of the Quaternary aquifer in the studied area. The model was run with input data during March 2005 and March 2006 concerning the following:

1- The initial values of dissolved salts concentration for March 2005 (Fig. 4) and final salts concentration for March 2006.

2-The values of specific yield (effective porosity) which have been considered by the hydraulic flow model by Abd El Aal ${ }^{[1]}$.

3- Advection, dispersion and diffusion parameters.

It has been found out that there are some discrepancies between the field measurements and computed values of the concentration of the dissolved salts in March 2006. These required some changes in the values of the effective porosity (Fig. 5) in order to attain better coincidence of the dissolved salts concentration. The values of calibrated effective porosity vary from 0.002 to 0.3 in the studied area. Accordingly, the hydrodynamic salts dispersivity model was calibrated with less discrepancy (Table 1) and (Fig. 6). The calibrated values 
of the effective porosity were applied once more to repeat the calibration run of the hydraulic flow model. During such iterative procedure, the calculated seepage velocity will be changed. Thus the plume length will also be changed until complete interaction between the flow and transport. The new seepage velocity is calculated. Consequently, final plume length is calculated and final longitudinal dispersivity is estimated

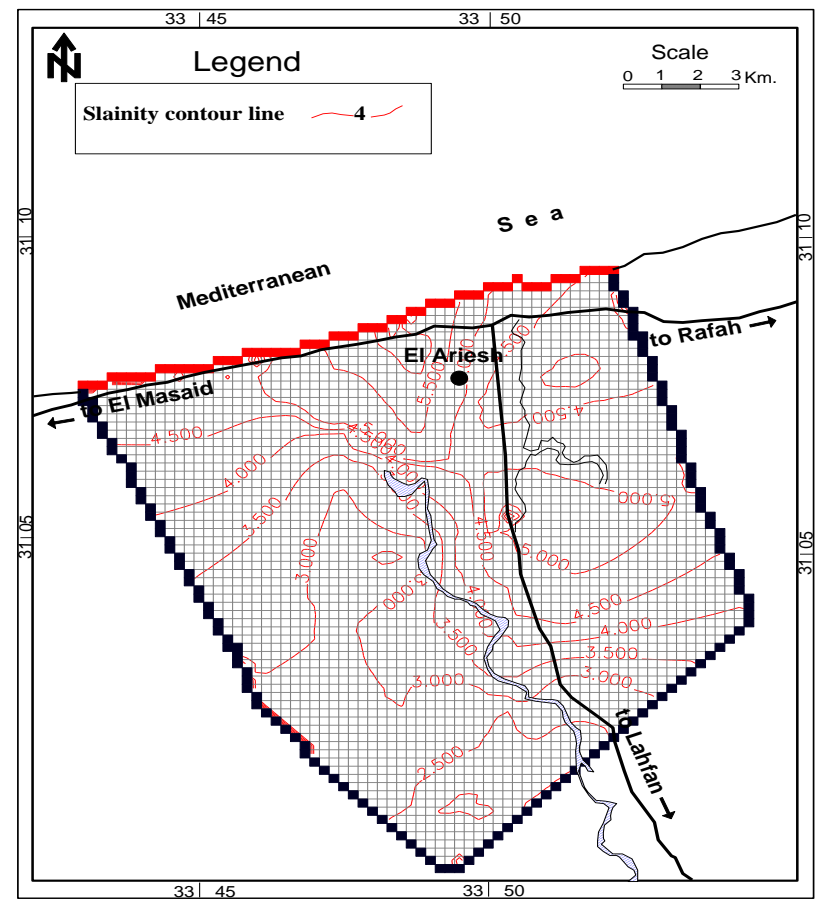

Fig. 4: Initial concentration of dissolved salts $\left(\mathrm{Kg} / \mathrm{m}^{3}\right)$ (March, 2005) for the quaternary aquifer in the Delta of Wadi El Arish, North East Sinai, Egypt.

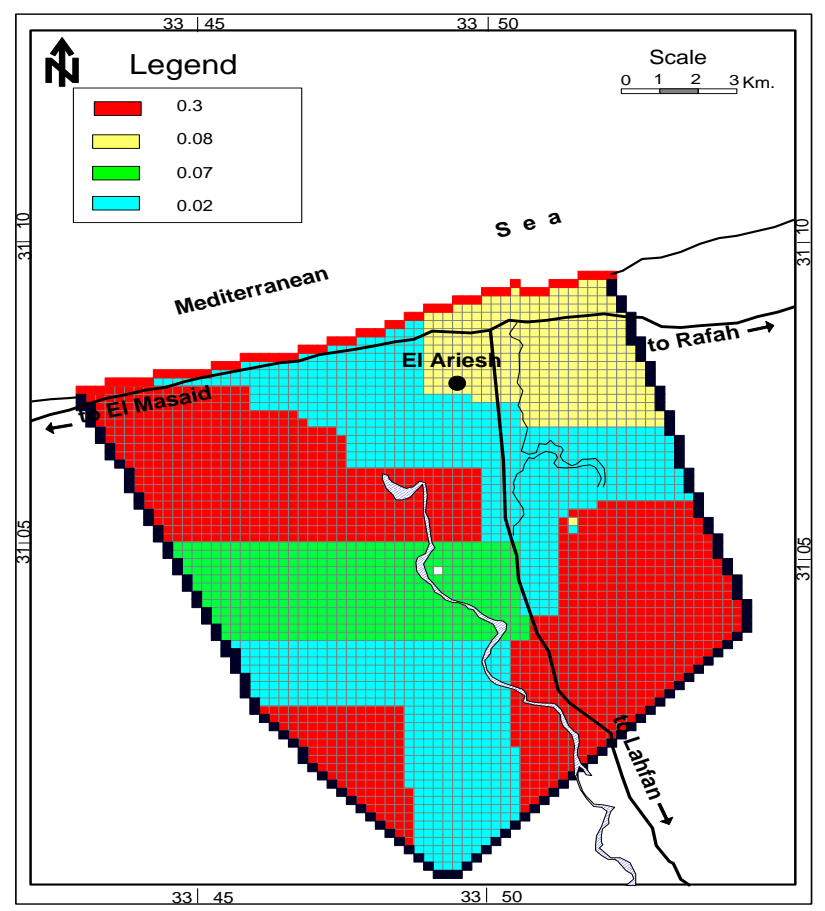

Fig. 5: Calibrated effective porosity for the quaternary aquifer in the Delta of Wadi El Arish, North East Sinai, Egypt. in the model. The longitudinal dispersivity is one tenth of plume length. Figure (6) shows the calibrated total dissolved salts for March 2006. The complete interaction between the hydraulic and salts model was in integration. The hydrodynamic salts dispersivity model was run monthly with the previous described input for the hydrological year 2005-2006. Twelve stress periods have been taken with 30 days for each in transient simulation.

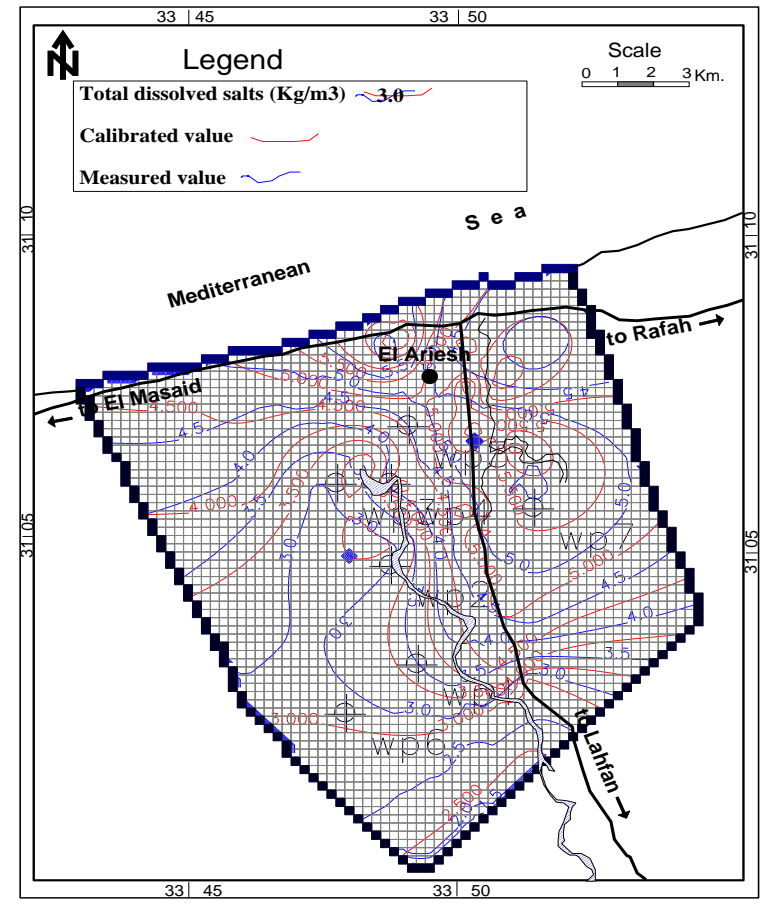

Fig. 6: Calibrated total dissolved salts $\left(\mathrm{Kg} / \mathrm{m}^{3}\right)$ (March, 2006) for the quaternary aquifer in the Delta of Wadi El Arish, North East Sinai, Egypt.

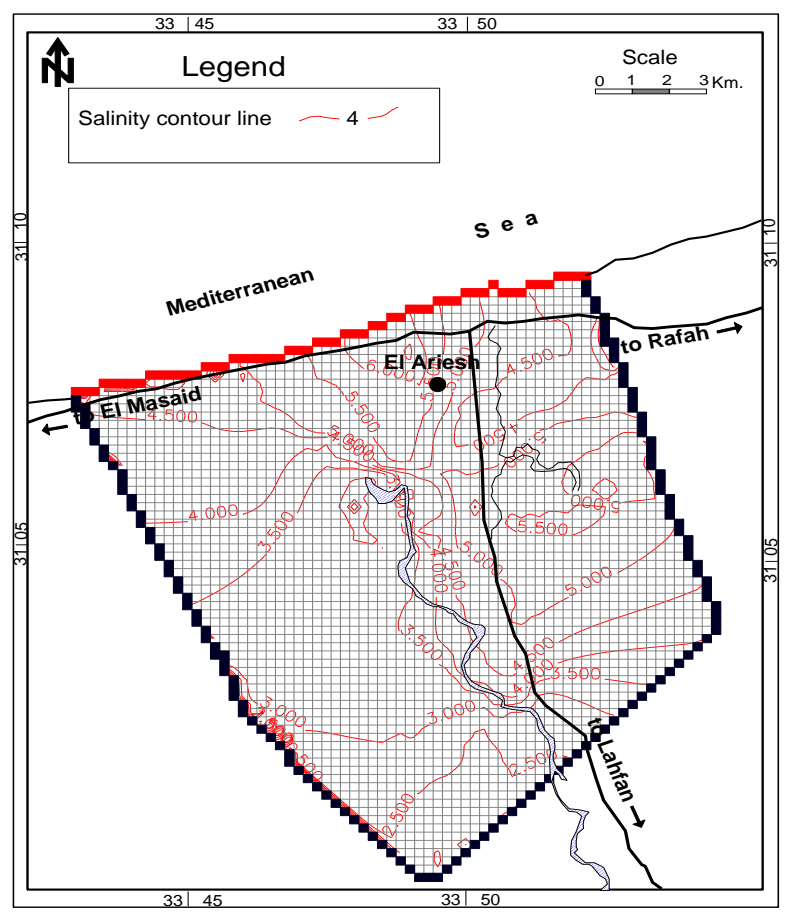

Fig. 7: Predicted dissolved salts $\left(\mathrm{Kg} / \mathrm{m}^{3}\right)(\mathrm{March}, 2006)$ for the quaternary aquifer in the Delta of Wadi El Arish, North East Sinai, Egypt. 
Table 1: Calibration table (selected reference points).

\begin{tabular}{|c|c|c|c|c|c|c|c|c|}
\hline \multicolumn{2}{|c|}{ Water points } & Wp1 & Wp2 & Wp3 & Wp4 & Wp5 & Wp6 & Wp7 \\
\hline \multirow{2}{*}{ 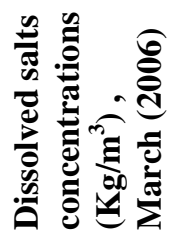 } & $\begin{array}{c}\text { Field } \\
\text { measurement }\end{array}$ & 3.728 & 3.185 & 3.011 & 4.504 & 4.708 & 3.074 & 5.665 \\
\hline & $\begin{array}{l}\text { Computed } \\
\text { after } \\
\text { calibration }\end{array}$ & 3.546 & 3.015 & 3.199 & 4.091 & 4.507 & 2.912 & 5.445 \\
\hline
\end{tabular}

\section{Dissolved salts prediction}

The proposed model was run for every year for ten years prediction (Figs. 7 and 8). It reveals the following results:

- Predicted rising in the dissolved salts concentration of the Quaternary aquifer from $0.1 \mathrm{~kg} / \mathrm{m}^{3}$ to $0.5 \mathrm{~kg} / \mathrm{m}^{3}$ along the coastal line of the studied area.

- Predicted rising in the dissolved salts concentration of the Quaternary aquifer from $0.5 \mathrm{~kg} / \mathrm{m}^{3}$ to $1.5 \mathrm{~kg} / \mathrm{m}^{3}$ in the inland area at $2 \mathrm{~km}$ away from the coast. It is considering as an area of over pumping.

- Predicted rising in the dissolved salts concentration of the Quaternary aquifer from $1.5 \mathrm{~kg} / \mathrm{m}^{3}$ to $2.5 \mathrm{~kg} / \mathrm{m}^{3}$ at one locality in a middle area in between.

- Predicted decreasing in the dissolved salts concentration of the Quaternary aquifer reaching 1 $\mathrm{kg} / \mathrm{m}^{3}$ in the eastern area at Wadi El Maazar and in the southern area at Lahfan fault. The predicted increasing of the dissolved salts concentration is due to the over pumping in such localities. While, the decreasing of the dissolved salts concentration is due to the contribution of water by sources of recharge from Wadi El Maazar and Lahfan fault.

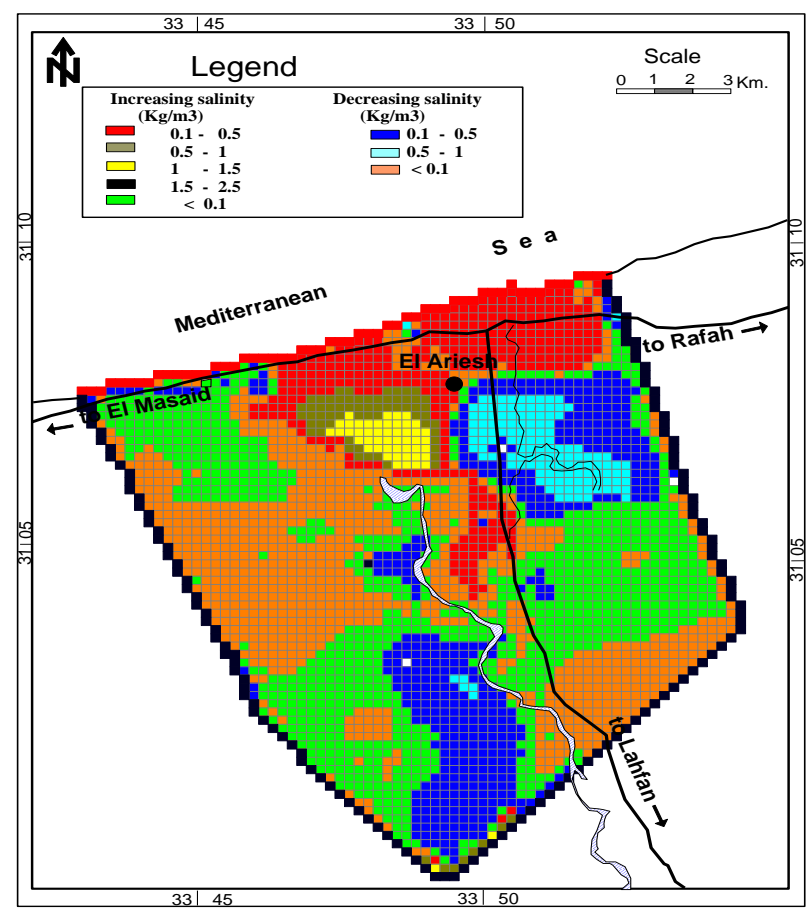

Fig. 8: Areas of decreasing and increasing of total dissolved salts concentration for the quaternary aquifer in the Delta of Wadi El Arish, North East Sinai, Egypt.

\section{Water and salt balances calculations}

The water balance and salt balance of the Quaternary aquifer in the Delta of Wadi El Arish are calculated by applying MODFLOW and MT3D programs. Using input data of recharge and discharge flow and salts rates through calibrated groundwater level and dissolved salts concentration. Thus:

Change in the groundwater storage $=$ Sum. of external hydrological stresses + subsurface water flow from boundaries

Change in the salts storage $=$ Sum. of external hydrochemical stresses + subsurface salts transport from boundaries

The external hydrological stresses of the studied area include the recharge and pumped water rates. While the external hydrochemical stresses can concise due to salts concentration of recharge and pumped water. From table (2), the water balance for the hydrological year, March 2005- March 2006, comprises the following values;

Inputs + outputs $= \pm \Delta$ storage

$(+7.49)+(-25.2$ out $)=-17.71$ million cubic meter (storage). The expected values for the hydrological year, March 2015-March 2016, are summarized as follows:

$(+19.53)+(-24.65)=-5.12$ million cubic meter (storage) From table (3), The salt balance is estimated for the hydrological year, March 2005 - March 2006, it comprises the following values;

Inputs + outputs $= \pm \Delta$ storage $(+37.68)+(-107.25)=-69.57$ million kilogram (storage) While the expected values for the hydrological year, March 2015- March 2016, are summarized as follows; $(+101.41)+(-108.71)=-7.3$ million kilogram (storage) .

In other words, through ten years prediction, there are 5.12 million cubic meter losses of groundwater storage which reflect other losses of salts storage reaching about 7.3 million kilogram. That means, every ten years ago the losses of groundwater reach about 5.12 million cubic meter associated with another losses of salt storage of about 7.3 million kilograms. Thus, a loss of 17.71 million cubic meters in groundwater storage since 1970 or through forty five years ago leads to a loss of about 69.57 million kilogram of salt storage. After ten years prediction (expected in 2016), the Quaternary aquifer will lose 22.86 million cubic meter from groundwater storage and 76.87 million kilogram from salts storage. Consequently the average salinity reaches $3.9 \mathrm{~kg} / \mathrm{m}^{3}$ corresponding to $3900 \mathrm{ppm}$. Such losses of groundwater 
and salt storages are attributed to the drop of the groundwater levels in the aquifer due to the over exploitation of the groundwater in the studied area. Over pumping of groundwater leads to encroachment of seawater with an amount of 11.05 million cubic meter every ten years with dissolved salts migration of about 62.37 million kilogram. The encroachment of seawater reflects both qualitative and quantitative deterioration in the groundwater in the studied area

Detection of the hydrodynamic salts dispersivities and advective zones

The heterogeneity of the complex water bearing formation in the studied area is leading to non uniform groundwater flow fields, where non uniform dissolved salts transport field is detected. Therefore, the retarded velocity in the groundwater for the Quaternary aquifer in the Delta of Wadi El Arish is calculated by applying retardation factor law ${ }^{[6]}$ and is estimated as a vector and value from MODPATH program. Figure (9) shows the distribution of dissolved salts velocities as a vector and values in each pixel in the complex water bearing formation in Delta of Wadi El Arish. It varies from $0.003 \mathrm{~m} /$ day to $2 \mathrm{~m} /$ day. The distribution of such variations is stated as follows:

- From $0.003 \mathrm{~m} /$ day to $0.01 \mathrm{~m} /$ day in some localities in the western and eastern areas.

- From $0.01 \mathrm{~m} /$ day to $0.09 \mathrm{~m} /$ day in some localities in the middle area.

- From $0.09 \mathrm{~m} /$ day to $0.9 \mathrm{~m} /$ day in some localities north of Lahfan fault and north of Wadi El Maazar.

- From $0.9 \mathrm{~m} /$ day to $2 \mathrm{~m} /$ day at some localities at Lahfan fault and Wadi El Maazar area and in the northern area at the Mediterranean Sea coast.

Such variations of retarded velocity are attributed to the effect of the probable structural faults as expressed in figure (2) in the studied area. The higher variations of retarded velocity values are located at the sources of groundwater recharge that expressed as follows:

- Subsurface flow from Wadi El Maazar in the eastern direction.

- Subsurface flow from Lahfan fault in the southern direction.

- Direct infiltration from rainfall in the northern direction at the Mediterranean Sea coast.

A mechanical dispersion is detected for the Quaternary aquifer in the Delta of Wadi El Arish. The mechanical dispersion is attributed to differences between actual particle velocity and seepage velocity for advective transport ${ }^{[12]}$. The hydrodynamic dispersivity being mechanical plus effective molecular diffusion ${ }^{[9]}$. In the current model, the mechanical dispersion is calculated from the following equation:

$\mathrm{D}=\mathrm{a}_{\mathrm{L}} \mathrm{V}^{[13]}$

Where :

$\mathrm{a}_{\mathrm{L}}$ : Is the longitudinal dispersivity $(\mathrm{m})$.

$\mathrm{V}$ : Is the fluid velocity ( $\mathrm{m} /$ day).

D: Is the mechanical dispersion $\left(\mathrm{m}^{2} / \mathrm{day}\right)$.

Figure (10) shows the distribution of mechanical salts dispersivites in the studied area. Its variation is conclu- ded as follows:

- Less than $5 \mathrm{~m}^{2} /$ day at some localities in the north western and south eastern directions.

- From $5 \mathrm{~m}^{2} /$ day to $10 \mathrm{~m}^{2} /$ day at some localities north to Lahfan fault, in the north eastern area and in the middle area.

- From $10 \mathrm{~m}^{2} /$ day to $20 \mathrm{~m}^{2} /$ day at some localities north to Lahfan fault and in the north eastern area as well as at the middle area and Wadi El Maazar area.

- From $20 \mathrm{~m}^{2} /$ day to $120 \mathrm{~m}^{2} /$ day at Lahfan fault and areas of the Delta of Wadi El Arish and Wadi El Maazar.

The higher variation of mechanical salts dispersivities (from $<5 \mathrm{~m}^{2} /$ day to $120 \mathrm{~m}^{2} /$ day are attributed to the following reasons:

1- Lowering of effective porosity in such areas which reaches 0.02 .

2- Higher drawdown in the groundwater which reaches about $5 \mathrm{~m}$ due to over pumping ${ }^{[1]}$.

Hydrodynamic salts dispersivities of the complex water bearing formation in the studied area are related to the interrelationship between advection, dispersion and diffusion. There are depending on the variations of Peclet number $(\mathrm{Pe})$. Peclect number $(\mathrm{Pe})$ expresses the importance of advection to dispersion in transporting equase compound. A large Pe value means that advection dominates, which may result in large concentration gradients. While, small Pe value suggests the dispersion dominates, which promotes mixing in the fluid phase ${ }^{[14]}$. Accordingly, Pe can be calculated from the following equation:

$P e=\frac{\bar{V} L}{D e f f+D}$

Where:

$\mathrm{Pe}:$ Is the Peclet number (dimensionless)

$\bar{V}$ : Is the fluid velocity (m/day).

$L:$ Is the arbitrarily characteristic length $(\mathrm{m})$

Deff : Is the effective molecular diffusion $\left(\mathrm{m}^{2} /\right.$ day)

$D$ : Is the mechanical dispersion $\left(\mathrm{m}^{2} /\right.$ day $)$

The variation of Peclet number $(\mathrm{Pe})$ in the studied area is shown in figure (11). It was found higher variation of Peclet number $(\mathrm{Pe})$ ranges from $>40$ in the eastern area at Wadi El Maazar and in the southern area at Lahfan fault as well as one locality in the northern area. Gradually the Peclet Number (Pe) decreases to reach 0.4 in some localities in the studied area. Consequently, the studied area is classified into five hydrodynamic salts dispersivities zones according to the classification of Bear and Verruijt ${ }^{[9]}$ and expressed in El Tabalwi ${ }^{[15]}$ as follows:

Zone (I): Where Pe ranges approximately between 0.4 and 5. The effects of mechanical dispersion and molecular diffusion are of the same order of magnitude. This zone indicates an area of miscible water (seawater and fresh groundwater in the northwestern direction and saltwater and fresh groundwater in the southeastern direction) occupying about $59.62 \mathrm{~km}^{2}$. 
Zone (II): Where Pe ranges approximately between 5 and 10. The spreading of dissolved salts is caused mainly by mechanical dispersion, where the dispersion is more than diffusion in its degree of magnitude. This zone indicates an area strongly affected by seawater encroachment in the northwestern direction and affected by saltwater in the southeastern direction and occupying about $40.25 \mathrm{~km}^{2}$.

Zone (III): Where Pe ranges approximately between 10 and 15 . The mechanical dispersion predominates and effect of molecular diffusion is negligible. This zone indicates an area influenced more or less by seawater encroachment and occupying about $18.31 \mathrm{~km}^{2}$.

Zone (IV): Where Pe ranges approximately between 15 and 40. It is characterized by pure mechanical dispersion, but beyond the range of Darcy's law. This zone indicates an area of probably or non- affected by seawater encroachment and occupying about $25.56 \mathrm{~km}^{2}$.

Zone (V): It is the zone of advection of dissolved salts, where the $\mathrm{Pe}>40$. This zone indicates a non affected area by seawater encroachment and occupying about $38.56 \mathrm{~km}^{2}$. This zone refers to non exploited groundwater or lower exploitation. It is considered as the rechargeable zone of groundwater regardless in one localities in the northeastern area which is refer to advective of miscible water.

It should be mentioned that the zone under only effective molecular diffusion does not appear in this study in megascopic level (field scale) but it can be appear in microscopic level in the media of isotropic and homogenous at Peclet number $(\mathrm{Pe})<0.4$ and very lower velocities or non-velocities. The hydrodynamic salts dispersivities of the Quaternary aquifer in the Delta of

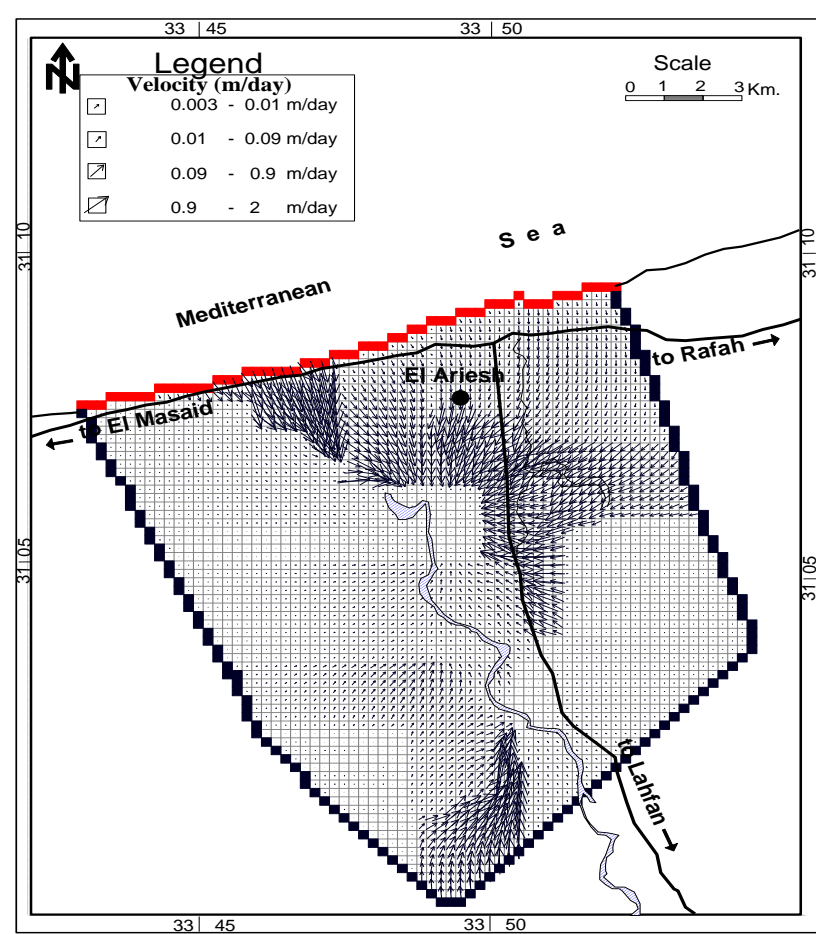

Fig. 9: The retarded velocity map as a vector and value of the quaternary aquifer in the Delta of Wadi El Arish, North East Sinai, Egypt.
Wadi El Arish occurs under the following conditions; lower diffusivity (lower aquifer efficiency) ranges from less than $10000 \mathrm{~m}^{2} /$ day to $20000 \mathrm{~m}^{2} /$ day. The advection processes occurs at higher diffusivity reaches 50000 $\mathrm{m}^{2} /$ day and higher hydraulic conductivity exceeds $>40$ $\mathrm{m} /$ day.

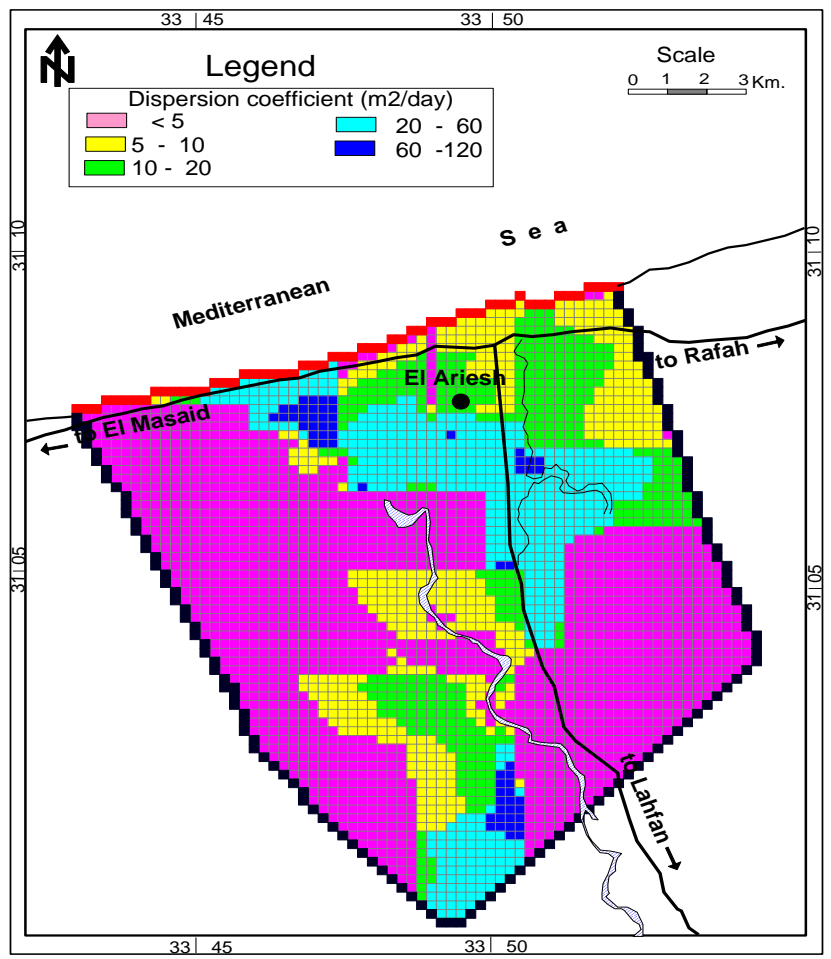

Fig. 10: The mechanical dispersion coefficient map of dissolved salts for the quaternary aquifer in the Delta of Wadi El Arish, North East Sinai, Egypt.

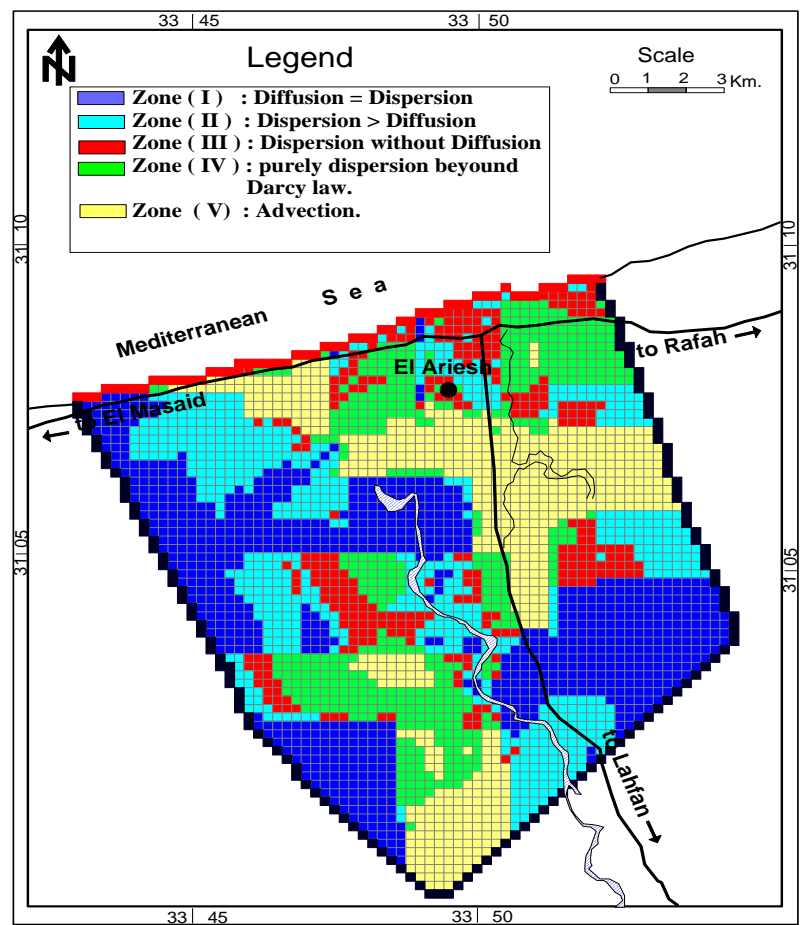

Fig. 11: The hydrodynamic salts dispersivities and advective zones in the quaternary aquifer in the Delta of Wadi El Arish, North East Sinai, Egypt. 
Table 2: Water balance of the Quaternary aquifer, Delta of Wadi El Arish $\left(10^{6} \mathrm{~m}^{3}\right)$.

\begin{tabular}{|c|c|c|c|c|c|c|}
\hline \multirow{2}{*}{ Element } & \multicolumn{3}{|c|}{ March 2005 - March 2006 } & \multicolumn{2}{c|}{ March 2015 - March 2016 } \\
\cline { 2 - 7 } & In & Out & Resultant & In & Out & Resultant \\
\hline Constant Head & 2.42 & 0.52 & 1.9 & 11.05 & 0 & 11.05 \\
\hline Pumped water & - & 24.65 & -24.65 & - & 24.65 & -24.65 \\
\hline Recharge & 4.25 & - & 4.25 & 4.25 & - & 4.25 \\
\hline $\begin{array}{c}\text { Head dependent } \\
\text { boundary }\end{array}$ & 0.82 & 0.03 & 0.79 & 4.23 & 0 & 4.23 \\
\hline Total & 7.49 & 25.2 & -17.71 & 19.53 & 24.65 & -5.12 \\
\hline \begin{tabular}{c} 
Groundwater loss $=$ \\
\hline
\end{tabular} & \multicolumn{7}{|c|}{17.71} & & 5.12 & \\
\hline
\end{tabular}

Table 3: Salt balance of the Quaternary aquifer, Delta of Wadi El Arish $\left(10^{6} \mathrm{Kg}\right)$.

\begin{tabular}{|c|c|c|c|c|c|c|}
\hline \multirow{2}{*}{ Element } & \multicolumn{3}{|c|}{ March 2005 - March 2006 } & \multicolumn{2}{c|}{ March 2015 - March 2016 } \\
\cline { 2 - 7 } & In & out & Resultant & In & out & Resultant \\
\hline $\begin{array}{c}\text { Constant } \\
\text { Concentration }\end{array}$ & 13.4 & 2.6 & 10.8 & 62.37 & 0 & 62.37 \\
\hline $\begin{array}{c}\text { Chemical } \\
\text { discharge }\end{array}$ & 0 & 104.56 & -104.56 & 0 & 108.71 & -108.71 \\
\hline Chemical recharge & 21.33 & 0 & 21.33 & 21.33 & 0 & 21.33 \\
\hline $\begin{array}{c}\text { Chemical } \\
\text { boundary }\end{array}$ & 2.95 & 0.09 & 2.86 & 17.71 & 0 & 17.71 \\
\hline $\begin{array}{c}\text { Total } \\
\text { Loss of dissolved } \\
\text { salts }\end{array}$ & 37.68 & 107.25 & -69.57 & 101.41 & 108.71 & -7.3 \\
\hline
\end{tabular}

\section{Rate of reaction}

The reaction rate expresses the decrease in the concentration of reactant, or the increase in the product, per unit time ${ }^{[13]}$. The rate of chemical reaction in the groundwater for the Quaternary aquifer in the Delta of Wadi El Arish is expressed by the Damkohler number ( $D a$ ). It is a dimensionless number and adopted by German chemist Gerhard Damkohler. According to the method of Zhu and Anderson [14], the Damkohler number is expressed by the following equation:

$$
D a=\frac{v \bar{S} a_{H^{+}}^{n} L}{C e q \overline{\mathrm{V}}}
$$

Where:

$D a$ : Is the Damkohler number

$v$ : Is the stoichiometry of component in the phase considered (e.g. $v=1$ for $\mathrm{Sio}_{2}$ in quartz).

$\bar{S}$ : Is the specific surface area $\left(\mathrm{m}^{2}\right.$ of mineral per $\mathrm{m}^{3}$ of fluid.

$a_{H^{+}}:$Is the hydrogen ion activity.

$n$ : Is the exponent for the hydrogen ion activity for specified reaction.

$L$ : Is an arbitrarily selected characteristic length.

$\overline{\mathrm{V}}$ : Is the true fluid velocity.

$\mathrm{Ceq}$ : Is the equilibrium concentration.
Stoichiometry is the term used for the balancing of equations, making sure that the same number of each kind of atom appears on both sides of each equation ${ }^{[13]}$. It is used to determine quantities such as the amount of product that can be produced with given reactants. The Damkohler number expresses the rate of reaction to the advection of fluid flow rate. A large $D a$ value means that the reaction is fast relative to transport and that aqueous concentration may change rapidly in time and space; the temporal and spatial scale of local equilibrium may be relatively small. Other method expresses Damkohler number is adopted by Bear and Bachmat [16, 17] and expressed by Bear and Cheng ${ }^{[13]}$, where, three kind of Damkohler number are demonstrated as follows:

$D m^{\prime} \equiv \frac{L c / V c}{1 / \lambda}=\frac{t c, a d v}{t c, \text { react }}=$

Ist kind Damkohler number

$D m^{\prime \prime} \equiv \frac{L^{2} c / D}{1 / \lambda}=\frac{t c, \text { diff }}{t c, \text { react }}=$ Pe Dm'=

2nd kind Damkohler number

$D m^{\prime \prime \prime}=\frac{D m^{\prime}}{P e}=\frac{D m^{\prime \prime}}{P e^{2}}=\frac{\lambda D}{V c^{2}}=\frac{t c, a d v}{t c, \text { diff }} \frac{t c, a d v}{t c, \text { react }}=$

3rd kind Damkohler number 
$L c:$ Is the characteristic length.

$V_{c}:$ Is the characteristic fluid velocity.

$\lambda$ : Is the first order rate constant for radioactive decay (hydrolysis and decay).

$t c, a d v$ : Is the characteristic time of advection.

tc, diff : Is the characteristic time of diffusion.

tc, react : Is the characteristic time of chemical reaction.

$t c, a d v \equiv \frac{L c}{V c}, \quad t c$, diff $\equiv \frac{L c^{2}}{D c}, t c$, react $\equiv \frac{1}{\lambda}$

Where:

$D c$ : Is the characteristic coefficients of dispersion.

From the above mentioned, the following steps are of important:

1- When $P e<<1$, transport by diffusion dominates over that by advection if also:

- $D m^{\prime \prime}>>1$, the reaction is referred to as a fast reaction.

- $D m^{\prime \prime}<<1$, the reaction is referred to as a slow reaction.

2- When $P e>>1$, transport by advection dominates over that by diffusion. If also:

- $D m^{\prime}>>1$, the reaction is referred to as a fast reaction.

- $D m^{\prime}<<1$, the reaction is referred to as a slow reaction.

3- When $P e \gg>1$, and also $D m^{\prime \prime}>>1$, the processes are dominated by advection and reaction. If also :

- $D m^{\prime}>>1$, the reaction is referred to as a (relatively) fast reaction.

- $D m^{\prime}<<1$, the reaction is referred to as a (relatively) slow reaction.

4- When $P e>>1$, and $D m^{\prime}<<1$, the situation implies $D m^{\prime \prime \prime}<<1$; and the processes are dominated by advection and reaction.

5- When $P e<<1$, and $D m^{\prime}<<1$, the situation implies $D m^{\prime \prime \prime}>>1$; and the processes are dominated by diffusion and reaction.

6- When $D m^{\prime}<<1$, the advection dominates over the source term. In other words, the time required for transport by advection is much smaller than that required for production $(=1 / \lambda)$ or removal by the source. Conversely, when $D m^{\prime}>>1$, the source term dominates over advection.

7- When $D m^{\prime \prime}<<1$, the spreading of the contaminant by diffusion dominates over the source term. In other words, the time required for spreading by diffusion is much smaller than that required for production or removal by the source. In the current study, we applied the method as expressed by Bear and Cheng ${ }^{[13]}$. Three maps are illustrated for application of the three kind of Damkohler number and one map for the variation Peclet number in two zones for the Quaternary aquifer in the Delta of Wadi El Arish (Figs. 12 and 15, inclusive). For the characteristic length $(L c)$, single common characteristic length, which is associated with the entire domain's dimension, the change in the concentration within the domain is considered. First order rate constant $(\lambda)$ is calculated as $1.91 \times 10^{-6}$ day $^{-1}$ in the current model. It is estimated by plotting $\ln \left(\mathrm{C}^{\circ} / \mathrm{C}\right) \mathrm{Vs} \mathrm{t}$ gives a straight line with slope equal to the rate constant for concentration data. This relation is adopted by Zhu and Anderson ${ }^{[14]}$. The slope will give $-k$ (first order rate constant). Where, $\mathrm{C}^{\mathrm{o}}$ is referred to the initial concentration at time zero and $\mathrm{C}$ is referred to final concentration at time one, two, etc., while $\mathrm{t}$ is the time. Thus :

$\mathrm{t}_{1 / 2}=\ln 2 / k=0.693 / k^{[13]}$

The half life time $\left(\mathrm{t}_{1 / 2}\right)$, may be considered as a characteristic reaction time ${ }^{[13]}$. While;

$\lambda=0.693 / \mathrm{t}_{1 / 2}{ }^{[6]}$

Finally $k$ is replaced by $\lambda^{[13]}$.

Fetter ${ }^{[18]}$ adopts the reaction rate constant $k$, to be $\ln 2 / \lambda$. From figures (12 and 15, inclusive), the following results are of important in the current study:

1- For $P e<<1$, (Blue area), the transport by diffusion dominates over that by advection. Where, $D m^{\prime \prime}<<1$, the reaction is referred to as a slow reaction. While at the area of Wadi El Maazar, $D m^{\prime \prime}>>1$, (yellow area), the reaction is referred to as a fast reaction.

2- For $P e>>1$, (Red area), the salts transport by advection dominates over that by diffusion. Where, $D m^{\prime}<<1$, the reaction is referred to as a slow reaction.

3- For the red area, where $P e>>1$, and $D m^{\prime}<<1$, the reaction is referred to as relatively slow reaction.

4- For $P e>>1$, (Red area) and $D m^{\prime}<<1$, and $D m^{\prime \prime \prime}<<1$, the processes in this localities are dominated by advection and reaction.

5- For $D^{\prime}<<1$, advection dominates over the source term, the time required for transport by advection is much smaller than that required for salts production.

6- For $D m^{\prime \prime}<<1$, the spreading of salts by diffusion dominates over the source of salts, where the time required for spreading by diffusion is much smaller than that required for removal of the salts by the source (production). From the above results, it can be concluded the following:

- The continental land area that is non-affected by seawater encroachment such as the area of Wadi El Maazar is characterized by dominating advection processes and implies advection and chemical reaction. In addition of fast chemical reaction and desorption processes are taking place.

- The continental land area that affected by seawater encroachment is characterized by spreading of salts by advection and diffusion and implies advection and chemical reaction. Furthermore slow and relatively slow chemical reaction and sorption processes are taking place.

- Fast accumulation of salts mass fraction on the solid surfaces of water bearing formation will increases the salts mass flux at different localities and affecting the efficiency of the Quaternary aquifer by decreasing the diffusivity of the aquifer in the studied area. Such accumulation changes the characteristics of the rock 
units into marine facies properties with lower hydraulic conductivity and intrinsic permeability. Also the salts mass accumulation decreases the tortousity factor of different deposits in the studied area.

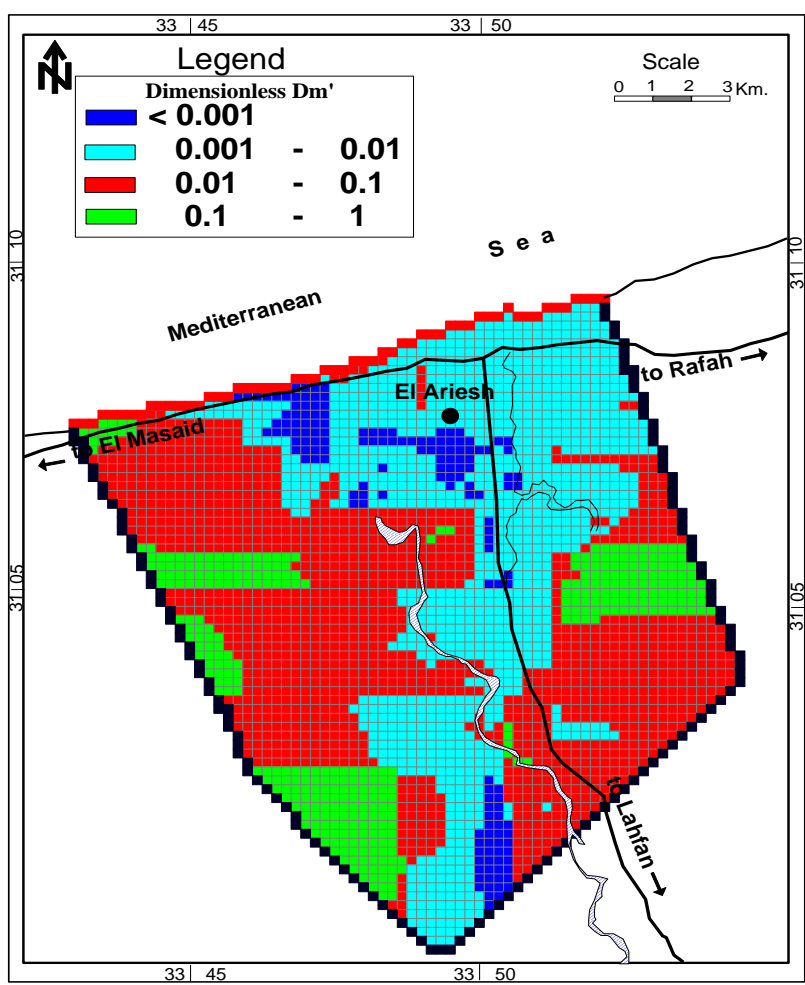

Fig. 12: First kind Damkohler number (Dm') for the quaternary aquifer in the Delta of Wadi El Arish, North East Sinai, Egypt.

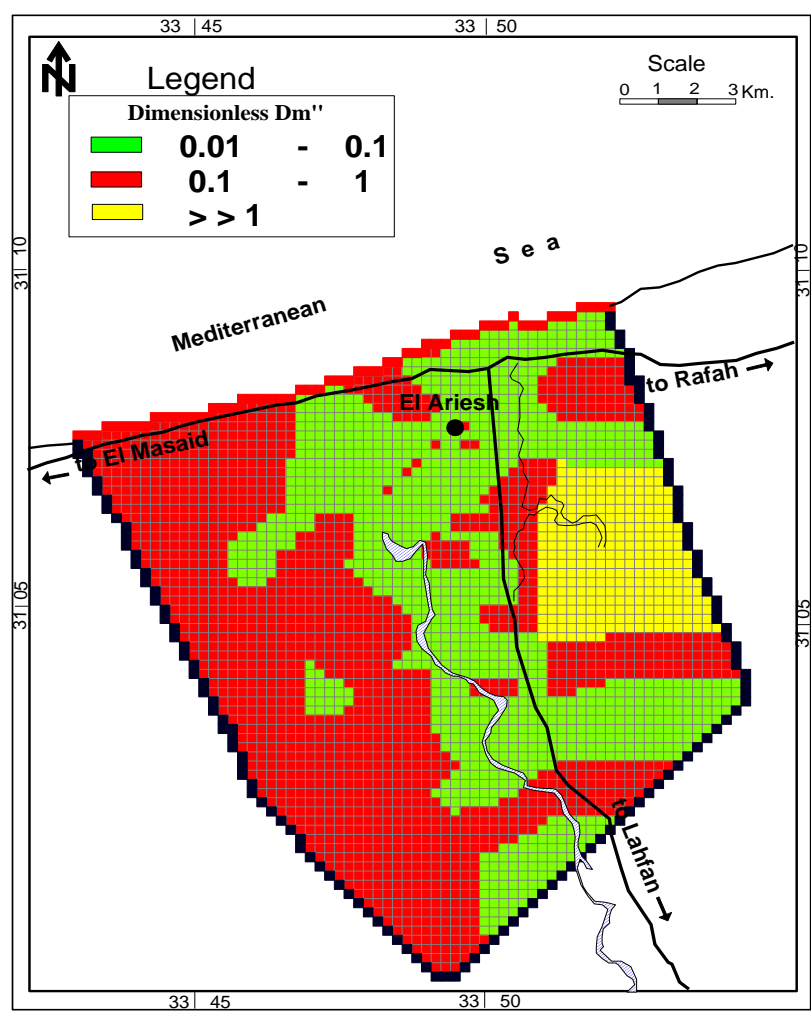

Fig. 13: Second kind Damkohler number (Dm") for the quaternary aquifer in the Delta of Wadi El Arish, North East Sinai, Egypt.
- The characteristic time of salts spreading by advection and diffusion is much smaller than that the characteristic time for chemical reaction (production) in the Quaternary aquifer in the Delta of Wadi El Arish.

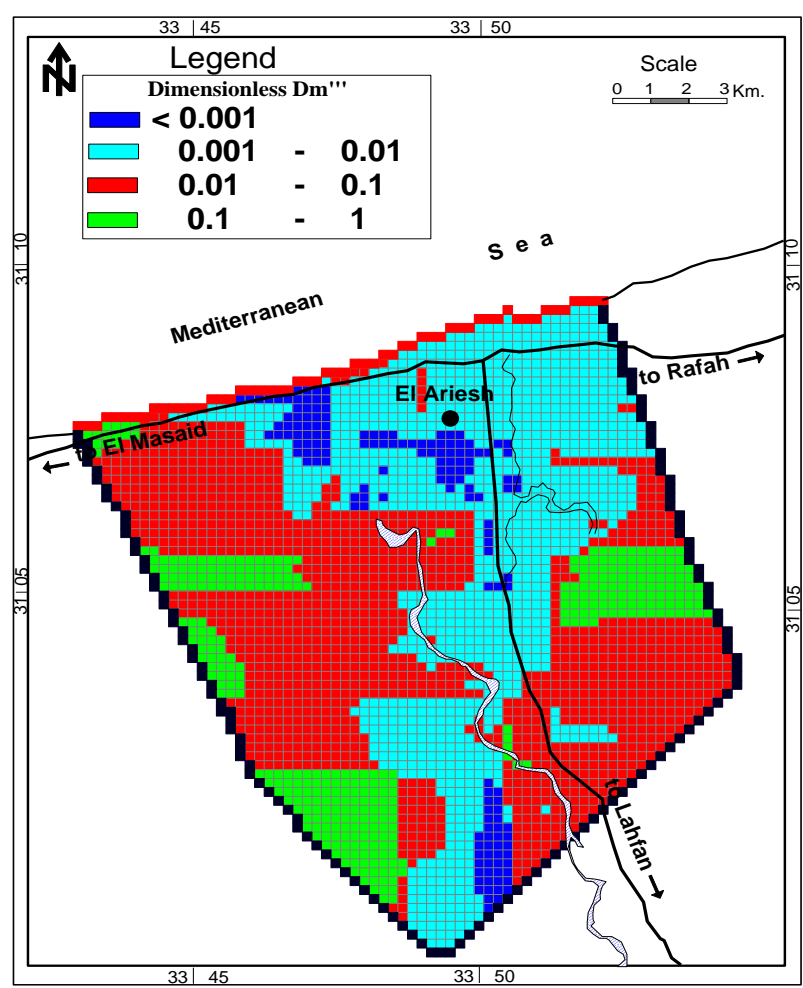

Fig. 14: Third kind Damkohler number (Dm"') for the quaternary aquifer in the Delta of Wadi El Arish, North East Sinai, Egypt.

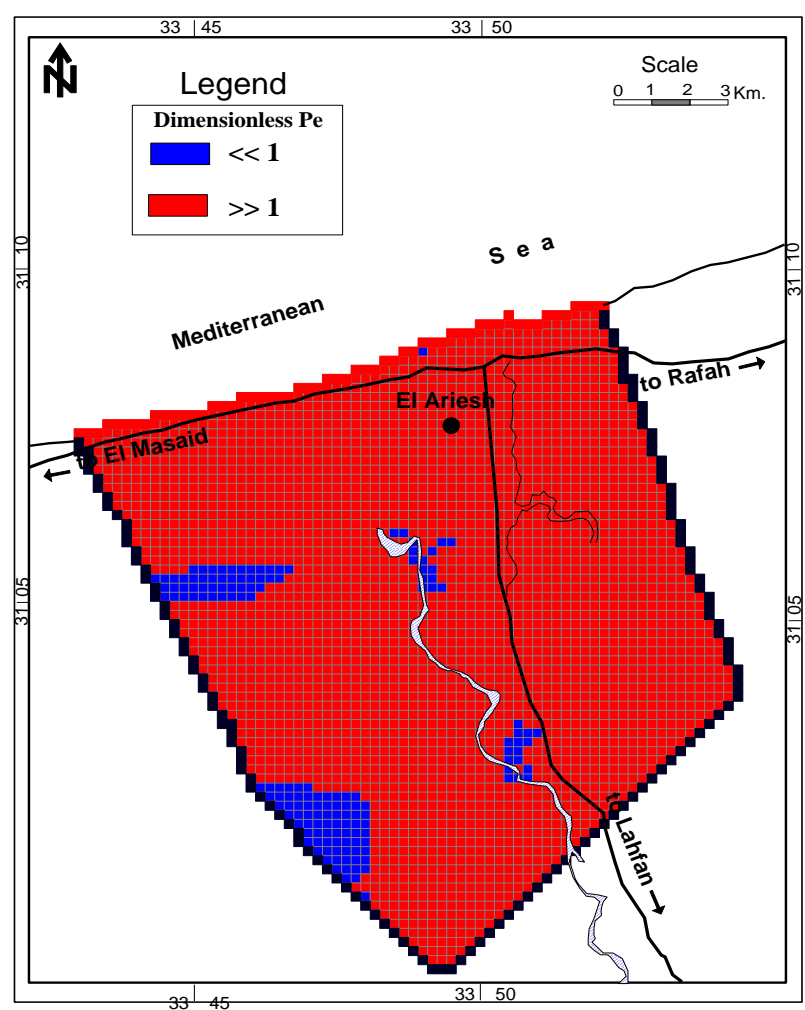

Fig. 15: Variations of Peclet number $(\mathrm{Pe})$ in two zones for the quaternary aquifer in the Delta of Wadi El Arish, North East Sinai, Egypt. 
Delineation of seawater-groundwater interface and travel time

The seawater zone in the Quaternary aquifer in the Delta of Wadi El Arish extends to some distance landward of the coast. As a consequence, a zone of transition exits in the aquifer across which the groundwater in the aquifer varies from the lighter groundwater flowing to the heavier seawater in the aquifer. This transition zone represents the interface zone between fresh groundwater and seawater. Seawater and fresh groundwater in the aquifer are often referred to as miscible water. They consist of single liquid phase-water-with different concentrations of total dissolved salts. Dispersion also induces an increase in the salt mass fraction in this zone. Both advection and dispersion contribute to the widening of the introducing seawater wedge in the vertical direction. In the proposed model, particle tracking method is used for delineation the interface zone. MODPATH program that linked with MODFLOW is used for track the salt paths. A solution that tracks particles influenced by advection and dispersion effect is a solution of the advectivedispersion equation ${ }^{[6]}$. This method is used by introducing many particles into the flow field and move in continuous spatial domain according to the velocities distribution calculated from the head generated by MODFLOW program. Then, the salt particles at selected different locations are tracked forward and backward along path lines to their source (Fig. 16). By forward and backward tracking, it can be noticed that the miscible and groundwater salt particles coincide at the line of interface, where the salt particles of groundwater change their direction in the studied area. While the mis-

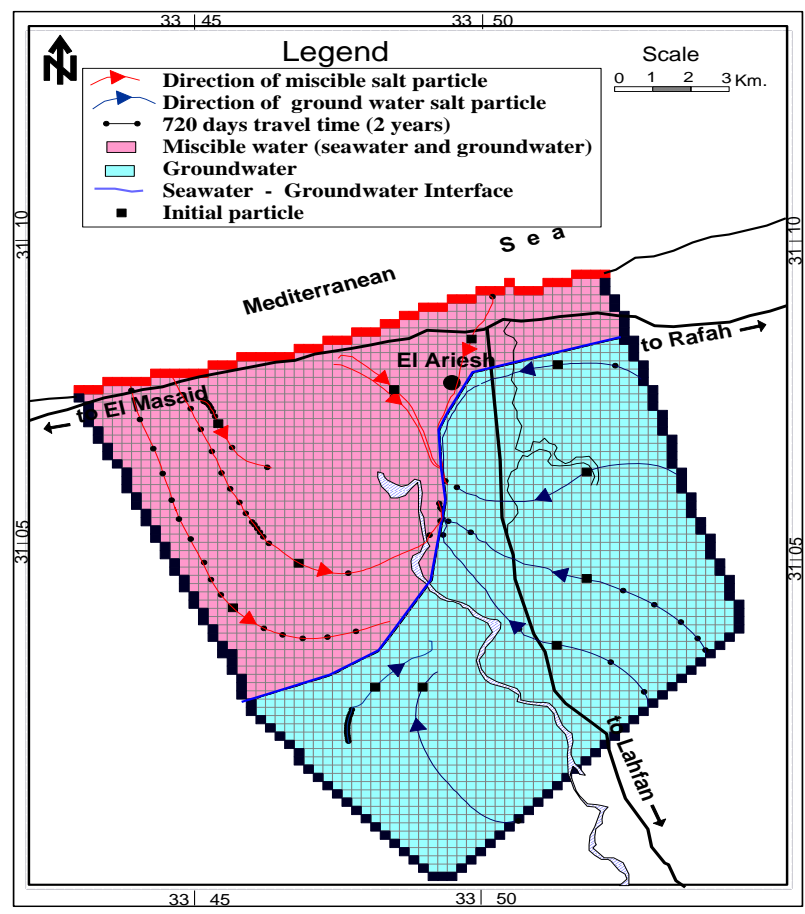

Fig. 16: Delineation of seawater-groundwater interface and travel time of salt particles at different locations for the quaternary aquifer in the Delta of Wadi El Arish, North East Sinai, Egypt cible salt particles move to inland distance ranges from 2 $\mathrm{km}$ in the northeastern direction to $10.25 \mathrm{~km}$ in the southwestern direction. Such changes in the salt particles direction of the groundwater are attributed to the encroachment of seawater with forces more than the forces of groundwater imposed by seawater (Hydrostatic pressure). They are proved by the differences in densities of seawater and fresh groundwater. Thus the interface of seawater - fresh groundwater is detected at the line of changing direction. From the particle tracking method, it can be calculated the travel time of salts particles from the rechargeable to the dischargeable areas. In the studied area (Fig. 16); the travel time of miscible salt particles varies from 2 years to 38 years. While the travel time of the groundwater salts particles varies from 2 years to 28 years.

The hydrodynamic salts dispersivity model can be applied in the coastal area of Mediterranean sea, the Red sea and in the Arab Gulf. It can be applied in the other coastal areas in the world and in the inland areas for the aquifer with higher salinity of groundwater.

\section{Recommendation}

The obtained results give rise to the following proposed recommendations for the groundwater aquifer remediation and sustainable development

1- The salts mass fraction in the subsurface regime in the studied area must be removed using "Double cell hydraulic isolation system" technique.

2- Drilling more wells in the coastal line of the studied area must be stopped.

3- Over pumping activities in the studied area must be controlled by installing water-meters on each well and proper regulation by an official law.

\section{Acknowledgement}

Praise to GOD, lord of the worlds, by the grace of whom the implementation of this work was possible.

\section{References}

1) Abd El Aal, T. H. G. (2013). Decision Support System Using Spatiotemporal GIS for Groundwater Resources with Application on Delta of Wadi ElArish. Ph.D. Thesis, Cairo Univ., Faculty of computers and information system, 172p.

2) Paver, G. L. and Jordan, J. N. (1956). Reconnaissance Hydrological and Geophysical Observations in North Sinai Coastal Area of Egypt. Bull. Inst. De’ Desert, Egypt, 7: 90p.

3) Taha, A. H. (1968). Geology of The Groundwater Supplies of El Arish-Rafaa Area, North Eastern Sinai, U.A.R. M.Sc. Thesis, Fac. Sci., Cairo Univ., Egypt., 120p.

4) El Said, H. M. (1994). Geochemistry of Groundwater in the Area between El-Qantara and El Arish, Noth Sinai. Ph.D. Thesis, Ain Shams Univ. Fac. Sci.

5) Chiang, H. W. and Kinzelbach, W. (1998). Processing Modflow, 3D-Groundwater Modeling With PMWIN, a Simulation System for Modeling Groundwater Flow and Pollution. ISBN 3-540-67744 
-S Springer - Verlag Berlin Heidelberg, New York.

6) Anderson, M. P. and Woessner, W. W. (1992). Applied Groundwater Modeling Simulation of Flow and Advective Transport. Academic Press. Inc San Diego, New York Boston, Landon, Sydney Tokyo Toronto, 381p.

7) Huyakorn, P. S. and Pinder, G. F. (1983). Computational Method in Subsurface flow. Acadimic Press, 473p.

8) Vance, D. B. (2002). Transverse Dispersion as the Natural Driving Force. http/www.2he4.net/ natat4disp.htm.

9) Bear J. and Verruijt A. (1987). Modeling Groundwater Flow and Pollution. D. Reidel Publishing Company, ordecht, Holland, 414p.

10) Miller J. and Hogan. H. (1997). Dispersion, Groundwater Pollution Primer, CE 45qu, Soil and groundwater pollution. Civil Engineering Dept, Virginia Tech.

11) Bedient, P. B., Rifai, H. S. and Newell, C. J. (1994). Groundwater Contamination Transport and Remediation. New Jersey, Prentice Hall, 541p.

12) Zheng, C. and Benett, G. D. (2002). Applied Cont- aminant Transport Modeling", Second Edition, John Wiley and Sons, Inc. New York, 621p.

13) Bear, J. and Alexander, C. D-H. (2010). Modeling Groundwater Flow and Contaminant Transport. Springer Dordrecht Heidelberg London New York, ISBN 978-1-4020-6681-8, 834p.

14) Zhu, C. and Anderson, G. (2002). Environmental Application of Geochemical Modeling. Cambridge University Press, The Pitt Building, Trumpington Sreet, Cambridge, United Kingdom, 294p.

15) EL Tablawi E. M. S. (2010). The Effect of Physical Processes on the Salts Transport in Sea water Intrusion areas (Case Study, El-Skeikh ZowiedRafah, North Sinai. Egyptian Journal of Pure and Applied Sciences, 48: 39-52.

16) Bear, J. and Bachmat, Y. (1990). Introduction to Modeling Phenomena of Transport in Porous Media. Kluwer, Dordrecht, 553p.

17) Bear, J. and Bachmat, Y. (1992). Deletion of Nondominant effect in Modeling Transport in Porous Media. Transp. Porous Media, 7:15-38.

18) Fetter C.W. (2008). Contaminant Hydrogeology. Waveland Press, Inc., Second Edition, 500p. 